\title{
Measles Virus Antibody in Cerebrospinal Fluids from Patients with Multiple Sclerosis
}

\author{
A. A. SALMI, M. PANELIUS, P. HALONEN, U. K. RINNE, K. PENTTINEN
}

British Medical fournal, 1972, 1, 477-479

\section{Summary}

A strong measles-specific gel precipitation reaction was found in the cerebrospinal fluid (C.S.F.) of two patients with multiple sclerosis (M.S.) (total of 15 tested). The serum and C.S.F. specimens from these two patients were tested for measles antibody by six assay methods. The results were compared with those obtained from serum and C.S.F. specimens of a patient with subacute sclerosing panencephalitis (S.S.P.E.). The gel precipitation line produced by the C.S.F. from the M.S. patients was identical with one of the three lines produced by the C.S.F. from the S.S.P.E. patient. The main antigenic component responsible for measles antibody appearing in the C.S.F. of the S.S.P.E. patient and the M.S. patients was also electrophoretically similar, and the corresponding antibody was associated with IgG. The serum/C.S.F. antibody titre ratios with the various assay methods used suggest that the C.S.F. antibodies are mainly to other than envelope components of measles virus. No complement-fixing antibody against 27 other viruses or Mycoplasma pneumoniae was found in the C.S.F. of the two M.S. patients.

\section{Introduction}

The aetiology of multiple sclerosis (M.S.) is still unknown. The importance of immunological and infective factors in the course of this disease has been extensively studied in recent years.

Epidemiological studies have shown that a common infection in childhood may manifest later as M.S. (Dean, 1967). Many viruses have been suggested to be the aetiological agent, but only measles virus antibody titres have consistently been found to be higher in M.S. patients than in the controls (Panelius et al., 1971). This suggests that at least in some M.S. patients measles virus may have aetiological significance. Only a few studies have been reported on viral antibodies in cerebrospinal fluid (C.S.F.) of M.S. patients, and no marked differences have been found between M.S. patients and controls (Adams and Imagawa, 1962; Sibley and Foley, 1963; Reed et al., 1964; Pette and Kuwert, 1965; Adams, 1967), except in one recent study by Brown et al. (1971).

In the present investigation the original material consisted of unconcentrated C.S.F. specimens from 15 unselected M.S. patients. These specimens were tested by the gel precipitation technique for measles antibodies. A strong gel precipitation reaction was found in two specimens, while three additional specimens produced a weak reaction. The strongly reacting C.S.F. specimens together with a C.S.F. specimen from a typical case of subacute sclerosing panencephalitis(S.S.P.E.) were extensively analysed with various serological tests. The three cases producing weak reactions were not studied further.

University of Turku, Turku, Finland

A. A. SALMI, M.D., Lecturer in Virology

M. PANELIUS, M.D., Lecturer of Neurology

P. HALONEN, M.D., Professor of Virology

U. K. RINNE, M.D., Professor of Neurology

University of Helsinki, Helsinki, Finland

K. PENTTINEN, M.D. Professor of Virology

\section{Case Reports}

Case 1.-A 51-year-old widow had her first symptom, weakness of the legs, at the age of 47 . Since then the disease had progressed and she had been bed-ridden for one year with high-grade spastic paralysis of her legs, and a slight paralysis and intention tremor in her arms. A partial sensory loss in the lower trunk and lower extremities, and decreased visual function with pallor of optic discs, also developed. She also had paralysis of the bladder, resulting in a chronic infection of the urinary tract. The amount of IgG was $11.1 \%$ of the total C.S.F. protein content of $55 \mathrm{mg} / 100 \mathrm{ml}$, the normal value being $6.1 \pm 2.2 \%$ (Link and Müller 1971). In agar gel electro-phoresis of C.S.F. three clearly separable IgG bands were found.

Case 2.-A 32-year-old merchant clerk had his first symptoms, gait disturbances, at the age of 29 . The course of the disease had been rather severe with four relapses and incomplete remissions. At the time of writing gait difficulties were due to severe ataxia and weakness of the legs. He also had intention tremor, rotatory nystagmus, a bilateral extensor plantar response, and decreased postural and vibration sense in the lower extremities. Optic discs showed bitemporal pallor. The amount of IgG was $12 \cdot 1 \%$ of the total C.S.F. protein content of $43 \mathrm{mg} / 100 \mathrm{ml}$. In agar gel electrophoresis of C.S.F. five IgG bands were found.

\section{Methods}

Viral antigens were prepared in cell cultures or embryonated eggs as described elsewhere (Vihma, 1969). Measles antigens for gel precipitation or immunoelectrophoresis were prepared in VERO cells by the total harvest method (Panelius et al., 1970).

\section{SEROLOGICAL METHODS}

Micromethods (Sever, 1962) for complement fixation tests and haemagglutination inhibition tests have been described elsewhere (Panelius et al., 1971). The test for inhibition of saltdependent haemagglutination was carried out by adding $0.8 \mathrm{M}$ $\left(\mathrm{NH}_{4}\right)_{2} \mathrm{SO}_{4}$ to the diluent of antigen according to the techniques of Schluederberg and Nakamura (1967). The platelet aggregation test is based on aggregation of human platelets by a complex between virus antibody and a small-sized virus antigen without added complement (Penttinen and Myllylä, 1968).

Gel precipitation tests were performed with a sensitive micromethod (Salmi, 1969). The volume of reagents used was 0.025 $\mathrm{ml}$ and the slides were incubated at room temperature for 90 hours. The results were read from photographs of the washed and stained slides. Neutralization tests were performed by plaque neutralization. The titre of specimen was the dilution neutralizing $90 \%$ of the plaques. The plaquing was performed on 5-cm plastic dishes with monolayers of VERO cells. The overlay consisted of BME diploid (Grand Island Biological Co., New York, U.S.A.) supplemented with $0.2 \%$ bovine serum albumin fraction V (Armour Pharmaceutical Co., Chicago, U.S.A.) and $0 \cdot 16 \%$ concentration of a commercial human gammaglobulin (Finnish Red Cross Blood Service, Helsinki, Finland).

Immunoelectrophoresis tests were performed on microscope slides with $0.05 \mathrm{M}$ phosphate buffer, $\mathrm{pH} 8.6$, and $1 \%$ agarose (L'Industrie Biologique Française, Genneviller, France) as the medium. Electrophoresis of the C.S.F. and serum specimens or measles antigens was carried out at $17 \mathrm{~V} / \mathrm{cm}$ for one to two hours, and the precipitates were developed at room temperature 
for 48 hours, measles antigen, specimens from the patients, or antiserum to human IgG being used.

Measles reference serum was obtained from a patient with S.S.P.E. Cerebrospinal fluid from the same patient was also used in gel precipitation tests.

\section{Results}

Cerebrospinal fluids from the two M.S. patients produced one strong line in gel precipitation tests against the measles antigen. A strong gel precipitation line was also produced by a measles antigen prepared from an attenuated vaccine strain, but no reaction was found with the antigens prepared from uninfected cells, cells infected with parainfluenza type 2 virus, or respiratory syncytial virus.

Comparison of the gel precipitation reaction of the C.S.F. from the M.S. patients with the reaction produced by serum and C.S.F. from the S.S.P.E. patient is shown in Fig. 1. The

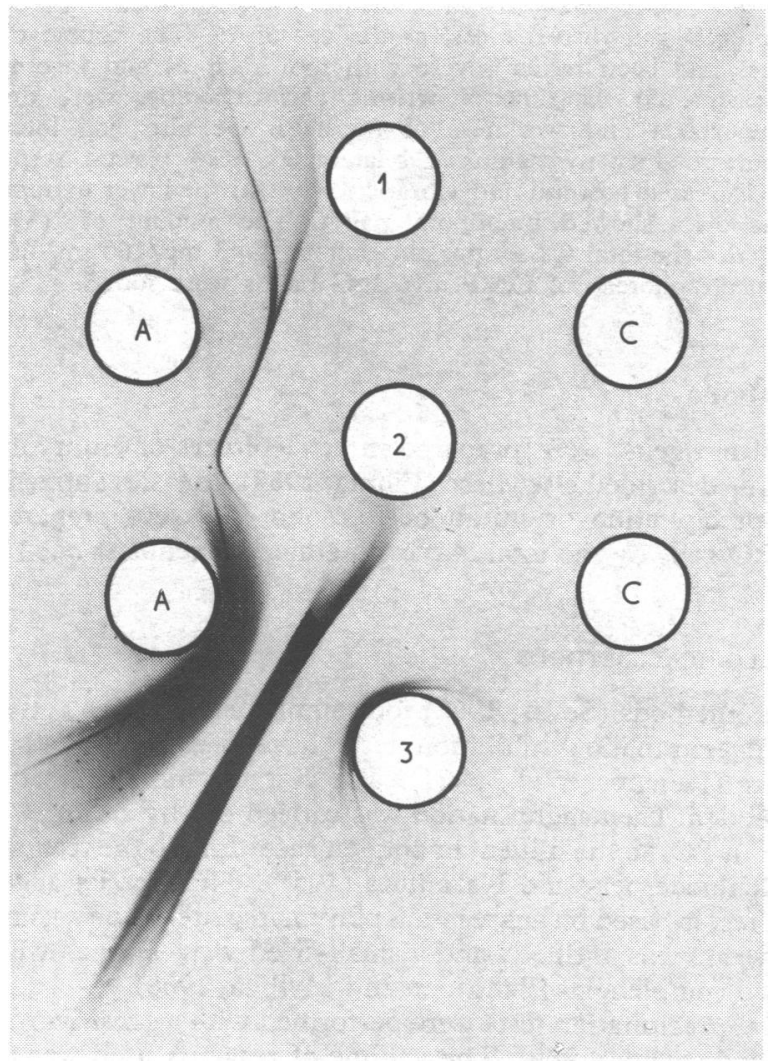

FIG. 1-Gel precipitation reactions of C.S.F. specimen of an M.S. patient (1) and C.S.F. (2) and serum (3) specimens of the S.S.P.E. patient against measles antigen (A) and corresponding control antigen (C).

gel precipitation antibodies in the C.S.F. of the M.S. patients have the same specificity as the antibodies in the C.S.F. of the S.S.P.E. patient, which is seen in the reaction of identity. When the sensitivity of the gel precipitation method was increased by decreasing the distance between the wells containing measles antigen and the C.S.F. specimens, three gel precipitation lines were produced by the C.S.F. from the S.S.P.E. patient (Fig. 2). Only one line was again produced by the C.S.F. from the M.S. patients and it was identical with one of the three lines produced by the C.S.F. from the S.S.P.E. patient.

The reactions after electrophoresis of measles antigen, followed by immunoprecipitation with C.S.F. specimens from the S.S.P.E. patient and an M.S. patient, are shown in Fig. 3. The results indicate that the main antigenic component responsible for the measles antibody appearing in the C.S.F. of the S.S.P.E. patient and the M.S. patients is also electrophoretically similar.

The C.S.F. specimens of the M.S. patients were concentrated 20 -fold and electrophoresis of the concentrated specimens was carried out for two hours with the same technique as described above for electrophoresis of antigen. The precipitates were developed with antihuman IgG and measles antigen. The results show that only a part of the total IgG in the C.S.F. is measlesspecific (Fig. 4).

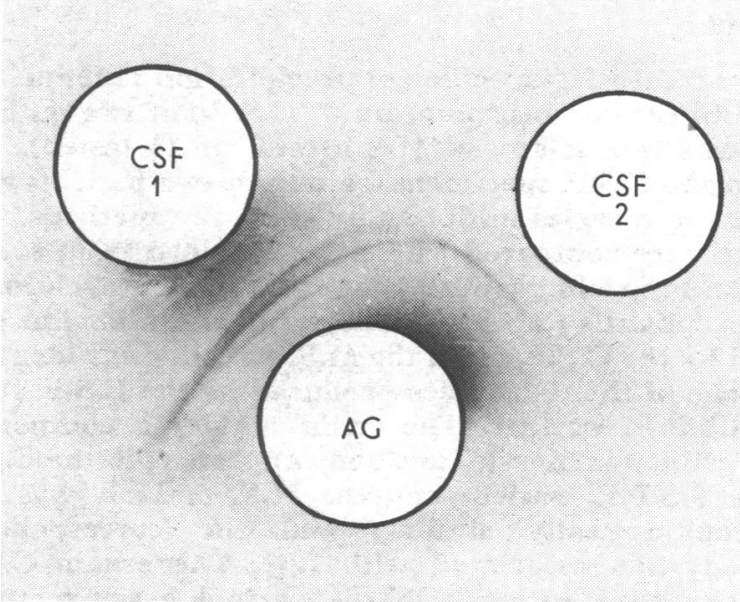

FIG. 2-Gel precipitation reaction of C.S.F. from the S.S.P.E. patient (1) and an M.S. patient (2) against measles antigen (AG).

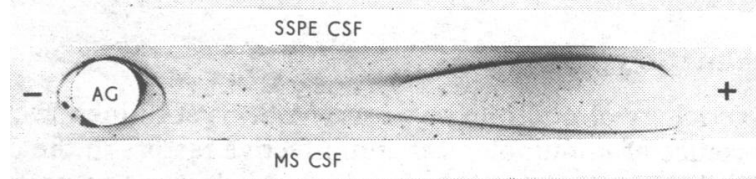

FIG. 3.-Immunoelectrophoresis reactions after electrophoresis of measles antigen followed by immunoprecipitation with C.S.F. from the S.S.P.E. patient and an M.S. patient.

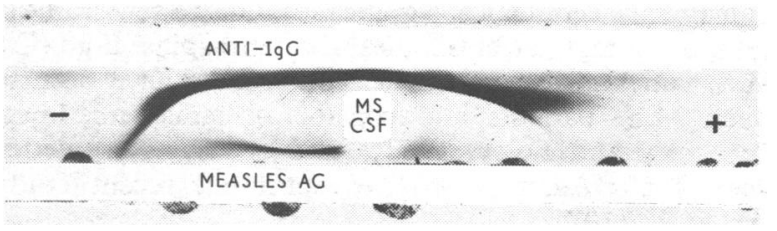

FIG. 4-Immunoelectrophoresis reactions after electrophoresis of C.S.F. from an M.S. patient followed by immunoprecipitation with antiserum to IgG, and with measles antigen.

The serum and C.S.F. specimens from the two M.S. patients and from the S.S.P.E. patient were tested for measles antibodies by using five additional assay methods. The results are shown in the Table, including serum/C.S.F. antibody titre ratios. These ratios are high in haemagglutination inhibition, salt-dependent haemagglutination inhibition, and neutralization tests, and are lower in complement fixation and platelet aggregation tests, indicating differences in antibody responses against envelope antigens and other measles antigens. The specimens were also tested by complement fixation for antibody to influenza $A$ and $B$, parainfluenza 1-3, adenoviruses, respiratory syncytial virus, measles, rubella, mumps, herpes simplex, herpes varicellazoster, cytomegalovirus, Coxsackie B1-5, Coxsackie A7 and A9, polio 1-3, E.C.H.O. 6, tickborne encephalitis (Russian 
Reciprocal Titres of Measles Antibodies in Serum and C.S.F. Specimens of Two Patients with M.S. and a Patient with S.S.P.E. and the Corresponding Serum/C.S.F. Titre Ratios

\begin{tabular}{|c|c|c|c|c|c|c|}
\hline \multirow{2}{*}{\multicolumn{2}{|c|}{$\begin{array}{l}\text { Patient and } \\
\text { Specimen }\end{array}$}} & \multicolumn{5}{|c|}{ Measles Antibodies and Serum/C.S.F. Ratio } \\
\hline & & \multirow{2}{*}{$\begin{array}{r}\text { H.I. } \\
80 \\
<1 \\
>80\end{array}$} & \multirow{2}{*}{ 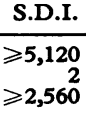 } & \multirow{2}{*}{$\begin{array}{r}\text { N.T. } \\
1,280 \\
8 \\
160\end{array}$} & \multirow{2}{*}{$\begin{array}{c}\text { C.F. } \\
32 \\
8 \\
4\end{array}$} & \multirow{2}{*}{$\begin{array}{r}\text { P.A. } \\
80 \\
4 \\
20\end{array}$} \\
\hline $\begin{array}{l}\text { Case } 1 \\
\text { (M.S.) }\end{array}$ & $\left\{\begin{array}{l}\text { Serum } \\
\text { C.S.F. } \\
\text { Ratio }\end{array}\right.$ & & & & & \\
\hline $\begin{array}{l}\text { Case } 2 \\
\text { (M.S.) }\end{array}$ & $\left\{\begin{array}{l}\text { Serum } \\
\text { C.S.F. } \\
\text { Ratio }\end{array}\right.$ & $\begin{array}{r}20 \\
>1 \\
>20\end{array}$ & $\begin{array}{r}80 \\
2 \\
40\end{array}$ & $\begin{array}{r}1,280 \\
16 \\
80\end{array}$ & $\begin{array}{r}128 \\
16 \\
8\end{array}$ & $\begin{array}{r}320 \\
8 \\
40\end{array}$ \\
\hline $\begin{array}{l}\text { Case } 3 \\
\text { (S.S.P.E.) }\end{array}$ & $\left\{\begin{array}{l}\text { Serum } \\
\text { C.S.F. } \\
\text { Ratio }\end{array}\right.$ & $\begin{array}{r}640 \\
16 \\
40\end{array}$ & $\begin{array}{r}\geqslant 5,120 \\
32 \\
\geqslant 160\end{array}$ & $\begin{array}{r}640 \\
64 \\
10\end{array}$ & $\begin{array}{r}512 \\
8 \\
64\end{array}$ & $\begin{array}{r}1,280 \\
16 \\
80\end{array}$ \\
\hline
\end{tabular}

H.I. = Haemagglutination inhibition. S.D.I. = Salt-dependent haemagglutination inhibition. N.T. $=$ Neutralization test. C.F. $=$ Complement fixation. P.A. = Platelet aggregation.

spring-summer encephalitis), reoviruses, vaccinia, ornithosis, Mycoplasma pneumoniae, and control antigen (VERO). The C.S.F. specimens were negative for each of these antigens and the serum titres varied from less than $1 / 4$ to $1 / 32$.

\section{Discussion}

In the two M.S. patients measles antibodies were detected in the C.S.F. with the five assay methods used and the titres were at levels comparable to those seen in the C.S.F. of the S.S.P.E. patient included in this study and also reported previously (Connolly et al., 1967). No other virus or mycoplasma antibodies present in the serum specimens were detectable in the C.S.F. of the M.S. patients. The serum/C.S.F. antibody ratios of M.S. patients assayed by complement fixation and platelet aggregation tests were similar to those described by Connolly et al. (1967) with complement fixation and haemagglutination inhibition tests on S.S.P.E. patients. These ratios are much lower than corresponding ratios described by Clarke et al. (1965) for polio antibody in M.S. patients. Accordingly, it is unlikely that all measles antibodies appearing in the C.S.F. of the M.S. patients have leaked through from the serum.

Active antibody production against measles in the central nervous system of S.S.P.E. patients has been described (Cutler et al., 1968) and at least a part of the IgG in the C.S.F. of M.S. patients is produced in their central nervous system (Cohen and Bannister, 1967). Furthermore, Millar et al. (1971) described the presence of measles-specific $\operatorname{IgM}$ in serum specimens from some M.S. patients, suggesting a prolonged antigenic stimulus. The possibility of active antibody production against measles virus in the central nervous system of these patients has to be considered.

Comparison of measles antibodies in the C.S.F. specimens of the M.S. patients with those of the S.S.P.E. patient in the gel precipitation test shows the reaction of identity. Only one strong gel precipitation line was produced by C.S.F. from the M.S. patients, whereas two or three measles-specific gel precipitation lines were produced by C.S.F. from the S.S.P.E. patient, as also found earlier by Palosuo et al. (1971). This finding, together with the finding that some of the serum C.S.F. antibody ratios were high, supports the idea that antibody production in the central nervous system of M.S. patients is probably directed principally against particular components of measles virus rather than the whole virus itself. These components are probably not associated with the measles envelope because only low haemagglutination inhibition, salt-dependent haemagglutination inhibition, and neutralization antibodies are de- tected in the C.S.F., these particular antibodies being directed against antigens derived from the virus envelope. However, in the serum these antibodies have much higher titres. It is possible that the active antibody production in the C.S.F. of these patients is mainly against non-envelope components of measles virus. These patients may have in their central nervous system a defective measles virus infection in which no envelope components are produced. Defective measles infection has been demonstrated in vitro in HeLa cells (Rustigian, 1966) and also in mouse brain cells (T. M. Bell, personal communication, 1971).

Although the results of the present study further suggest an active antibody production against measles in the central nervous system of some M.S. patients, it does not prove the aetiological association between measles virus and M.S. Measles virus may be the agent which triggers the mechanism leading to the demyelinating disease, but measles antibody production could also be a secondary phenomenon after release of measles virus components from the glial cells destroyed by other aetiological factors. The presence of measles virus components in brain cells may be residual from a measles infection in childhood, which commonly involves the central nervous system (Ojala, 1947; Pampiglione, 1964).

Since this study was completed Brown et al. (1971) have reported measles antibody titres in the C.S.F. and serum from M.S. patients and controls. Their results also indicate a higher rate of positive C.S.F. specimens from M.S. patients by complement fixation test than by haemagglutination inhibition or neutralization test. The possibility of active antibody production against measles virus in the central nervous system of M.S. patients is further supported by the lack of overall correlation between C.S.F. and serum antibody levels found by Brown et al. (1971).

The technical help of Mrs. Maija Rautiainen is gratefully acknowledged. This study was supported by grants from the Yriö Jahnsson Foundation and from the National Research Council for Medical Sciences, Finland, and the Sigrid Juselius Foundation, Finland.

\section{References}

Adams, J. M. (1967). Neurology, 17, 707.

Adams, J. M., and Imagawa, D. T. (1962). Proceedings of the Society for Experimental Biology and Medicine, 111, 562.

Brown, P., Cathala, F., Gajdusek, D. C., and Gibbs, C. J. (1971). Proceedings of the Society for Experimental Biology and Medicine, 137, 956.

Clarke, J. K., Dane, D. S., and Dick, W. A. (1965). Brain, 88, 953.

Cohen, S., and Bannister, R. (1967). Lancet, 1, 366.

Connolly, J. H., Allen, I. V., Hurwitz, L. J., and Millar, J. H. D. (1967)

Lancet, 1, 542 .
Cutler, R. W. P., Merler, E., and Hammerstad, J. P. (1968). Neurology, 18 , No. 1 , pt. 2 , p. 129 .

Dean, G. (1967). British Medical fournal, 2, 724.

Link, H., and Müller, R. (1971). Archives of Neurology, 25, 326.

Millar, J. H. D., et al. (1971). British Medical fournal, 2, 378.

Ojala, A. (1947). Annales Medicinae Internae Fenniae, 36, 321.

Palosuo, T., Salmi, A. A., and Pettay, O. (1971). Archiv für die gesamte Virusforschung, 35, 45 .

Pampiglione, G. (1964). British Medical fournal, 2, 1296.

Panelius, M., Salmi, A., and Halonen, P. (1970). Acta Pathologica et Microbiologica Scandinavica, 78 B, 588 .

Panelius, M., Salmi, A. A., Halonen, P., and Penttinen, K. (1971). Acto Neurologica Scandinavica, 47, 315.

Penttinen, K., and Myllyla, G. (1968). Annales Medicinae Experimentalis et Biologiae Fenniae, 46, 188.

Pette, E., and Kuwert, E. (1965). Archiv für die gesamte Virusforschung, 16,

141. $\log y, 10,402$.

Rustigan, R. (1966). Fournal of Bacteriology, 92, 1805.

Sultigan, R. (1966). Fournal of Bacteriology, 92, 1805.

Salmi, A. (1969). Acta Pathologica et Microbiologica Scandinavica,

Schluederberg, A., and Nakamura, M. (1967). Virology,

Sibley, W. A., and Foley, J. M. (1963). Transactions of the American Neurological Association, 88, 277.

Vihma, L. (1969). Acta Paediatrica Scandinavica, 58, Suppl. No. 192. 